G. Yaskov ${ }^{1}$, S. Shekhovtsov ${ }^{2}$

${ }^{1}$ A. Pidgorny Institute of Mechanical Engineering Problems of the NAS of Ukraine, Kharkiv, Ukraine

${ }^{2}$ Kharkiv National University of Internal Affairs, Kharkiv, Ukraine

\title{
METHODOLOGICAL BASIS OF SOLVING SPHERE PACKING PROBLEM: TRANSFORMATION OF KNAPSACK PROBLEM TO OPEN DIMENSION PROBLEM
}

\begin{abstract}
The subject matter of the paper is the problem of optimal packing of spheres of different dimension into a container of arbitrary geometric shape. The goal is to construct a mathematical model which associates different statements of the problem. Sphere packing problems (SPP) are combinatorial optimization problems known as cutting and packing problems. SPP consists in placement of a given set of spheres with given radii into a container of regular or irregular geometric shape. The task to be solved are: to investigate mathematical models of the two formulations according to the classification of cutting and packing problems: knapsack problems (KP) and open dimension problems (ODP); to construct a mathematical model which allow solve KP as ODP. The methods used are: the phi-function technique, increasing the problem dimension, homothetic transformations. KP is formulated as mixed discrete-continuous programming problem. A new approach which reduces solving KP to solving ODP for packing unequal and equal spheres into a container with the variable coefficient of homothety and allows adopt the jump algorithm for KP is suggested. To this end, for a given set of spheres KP is stated as a nonlinear programming problem in which the coefficient of homothety is an independent variable bounded below. The unit value of the coefficient corresponds to the original size of the container. A graphical illustration of the optimization process is presented. Conclusions. The approach suggested is a methodological basis for solving SPP. The generality of the approach lies in the fact that solving SPP does not depend on its formulation (KP or ODP). The approach is suitable for packing unequal and equal spheres into containers of arbitrary spatial shapes for which phifunctions can be constructed.
\end{abstract}

Keyw ord s: sphere; hypersphere; sphere packing; knapsack problem; open dimension problem; nonlinear optimization.

\section{Introduction}

Sphere packing problems (SPP) are known to be NP-hard combinatorial optimization problems. These problems relate to the field of cutting and packing. SPP consists in placement of a given set of spheres with known radii into a container of regular or irregular geometric shape. In the general case, spheres can be of different dimension $(2 \mathrm{D}$ - circles, 3D - hard spheres, $\mathrm{nD}$ - hard hyperspheres).

SPP have a wide spectrum of scientific and practical applications. In two and three dimensions there are real-world applications in a range of industries, for example, the textile, apparel, automobile, aerospace and chemical industries [1], in particular, in additive manufacturing for optimization of product's topology [2] and in medicine for automated radio-surgical treatment planning [3]. In higher dimensions packing hard hyperspheres is used to model geometrical frustration and the geometry of the crystalline state [4]. Packing hyperspheres may be used in the numerical evaluation of integrals, either on the surface of a sphere or in its interior [5]. The problems also arise in coding theory, digital communications and storage, for example, $\mathrm{CD}$, cell phones, and the Internet $[5,6]$.

Waescher et al. [7] introduce the classification of cutting and packing problems. According to the classification two classes of packing problems KP and ODP are considered depending on characteristics of dimensions (sizes) of a container (fixed dimensions or at least one variable dimension) and the form of objective function (maximum packing factor or minimum size). $\mathrm{KP}$ consists in packing of spheres with given radii from a collection into a container of fixed sizes with maximum packing factor. In ODP all spheres from the collection should be packed into the container with several fixed sizes and a variable metric characterestic that has to be minimized.

Some researchers (for example, $[8,9]$ ) use the KP formulation. If it is necessary to solve the ODP, a dichotomous search for the variable size is used, i.e. ODP solution is reduced to solving a KP sequence, which leads to an increase in counting time.

In [10] the SPP is formulated as ODP. As the minimum container size, the radius, length, height, perimeter, area, volume, surface area are used. A nonlinear twice-differentiable mathematical model is proposed, which allows to obtain a local minimum of the problem.

In $[11,12]$ mathematical models based on increasing the problem dimension are used to solve KP for equal spheres. Radii of the spheres are temporary assumed to be variable and the sum of the sphere volumes is maximized until the radii reach their starting values. Such an optimization procedure provides growing microcopies of the spheres to its original sizes. The multistart strategy is applied to obtain a better solution of KP. If the global maximum of the objective can not be obtained, then the number of spheres to be packed into container is reduced until a feasible packing is calculated.

The idea of additional variable metric characteristics was extended for unequal spheres. Papers $[13,14]$ propose adaptations of the efficient jump algorithm [15] for different dimension. The jump algorithm realizes a directed transition from one local minimum of ODP to another to yield an improvement of the objective.

This paper continues to investigate mathematical models of KP and ODP. A new approach which reduces solving KP to solving ODP for packing spheres into a container with the variable coefficient of homothety and 
allows adopt the jump algorithm for KP is suggested. The approach is a methodological basis for solving SPP which does not depend on the problem statement (KP or ODP).

\section{Mathematical Models of KP and ODP}

$\mathrm{KP}$ is stated as follows. Let there be given a container $C \subset \mathbf{R}^{d}$ of fixed sizes and a collection of spheres $S_{i}\left(u_{i}\right) \subset \mathbf{R}^{d}, i \in I_{N}=\{1, \ldots, N\}$, with known radii. The problem consists in packing a subset spheres from the collection $S_{i}\left(u_{i}\right), i \in I_{N}$ without overllapping inside $C$ yielding the maximum packing factor. Here $u_{i}$ is a motion vector of $S_{i}, i \in I_{N}, d \geq 2$ is space dimension.

Let $K$ types of spheres from the collection $S_{i}\left(u_{i}\right), i \in I_{N}$ with radii $r_{k}$, be considered, $k \in I_{K}=\{1,2, \ldots, K\}$. We denote the number of spheres of the $k$-th type that can be fully arranged inside $C$ by $n_{k}, k \in I_{K}$, and generate a tuple $t=\left(n_{1}, n_{2}, \ldots ., n_{K}\right)$. Each tuple $t$ has to involve at least one nonzero element $n_{k}, k \in I_{K}$. We denote a set of possible tuples $t$ by $T$. The cardinality of $T$ is $\prod_{k=1}^{K}\left(n_{k}+1\right)$. We form a subset $S^{t}$ of spheres $S_{j}\left(u_{j}\right), j \in J=\{1,2, \ldots, n\}$ from the collection $S_{i}\left(u_{i}\right), i \in I_{N}$ with respect to the tuple $t=\left(n_{1}, n_{2}, \ldots, n_{K}\right)$, where $n=\sum_{k=1}^{K} n_{k}$.

A subset $S^{t}$ taking into account translation is denoted by $S^{t}(v)=\left\{E_{j}\left(v_{j}\right), j \in J\right\}, \quad$ where $v=\left(v_{1}, v_{2}, \ldots, v_{n}\right) \in \mathbf{R}^{d n} \quad$ is a vector of placement parameters of spheres $S_{j}\left(v_{j}\right), j \in J$, $v_{j}=\left(x_{1 j}, x_{2 j}, \ldots, x_{d j}\right)$ is a translation vector of $S_{j}\left(v_{j}\right)$.

Thus, KP can be formulated as to find such subset of spheres $S^{t}\left(v^{*}\right), q \in I_{Q}$, that can be fully arranged within the container $C$ with the maximum packing factor:

$$
\begin{gathered}
F^{*}=F\left(v^{*}, t^{*}\right)=\max _{t \in T} \sum_{j \in J}\left(r_{j}\right)^{d},(v, t) \in W \subset \mathbf{R}^{d n} \times T, \\
W=\left\{(v, t): \Phi_{i j}\left(v_{i}, v_{j}\right) \geq 0, i, j \in J, i>j,\right. \\
\left.\Phi_{i}\left(v_{i}\right) \geq 0, i \in J\right\},
\end{gathered}
$$

where $\Phi_{i}\left(v_{i}\right)$ is a phi-function for $S_{i} \in S^{t}$ and the object $C^{*}=R^{2} \backslash \operatorname{int} C$,

$$
\Phi_{i j}\left(v_{i}, v_{j}\right)=\sum_{k=1}^{d}\left(x_{k i}-x_{k j}\right)^{2}-\left(r_{i}+r_{j}\right)^{2} \geq 0 .
$$

To solve problem (1)-(2) one should realised an exhastive search of all elements of the set $T$ and try to find a packing of spheres according to each tuple $t \in T$.
ODP has another formulation. A collection of spheres $S_{i}\left(u_{i}\right), i \in I_{N}$, have to be packed into the container $C$ of a variable size (area, volume, or a metric characteristic) that has to be minimized.

A mathematical model of ODP can be presented as to find

$$
\mu^{*}=\min \mu \text {, s.t. } Y=(u, \mu) \in \tilde{W} \subset \mathbf{R}^{d N+1},
$$

where $\mu$ is a metric characteristic to be optimized,

$$
\begin{gathered}
\tilde{W}=\left\{Y: \Phi_{i j}\left(u_{i}, u_{j}\right) \geq 0,0<i<j \in I_{N},\right. \\
\left.\Phi_{i}\left(u_{i}, \mu\right) \geq 0, i \in I_{N}\right\} .
\end{gathered}
$$

Inequality

$$
\Phi_{i j}\left(u_{i}, u_{j}\right)=\sum_{k=1}^{d}\left(x_{k i}-x_{k j}\right)^{2}-\left(r_{i}+r_{j}\right)^{2} \geq 0
$$

guarantees non-overlapping spheres $S_{i}$ and $S_{j}$. Inequality $\Phi_{i}\left(u_{i}, \mu\right) \geq 0$ provides a placement of $S_{i}\left(u_{i}\right)$ within $C$.

\section{Transformation of knapsack problem to open dimension problem}

The increase in the dimension of the problem due to the introduction of variable metric characteristics of the objects to be placed was successful in solving the problems of packing equal and unequal spheres $[11,14]$. In this regard, this approach is distributed to the metric characteristics of the container. Taking into account the ODP peculiarities, it is convenient to choose a coefficient homothety of the container as such a characteristic. With the ability to proportionally resize the container, one can solve KP (1)-(2) for a tuple as ODP (3)-(4). The homothety coefficient $\lambda$ is associated as the open dimension parameter which is the metric characteristic to be minimized.

Let $C(\lambda)=\left\{\lambda x \in \mathbf{R}^{d}: x \in C\right\}$, where $\lambda$ is a scaling parameter.

To describe placement (non-overlapping and containment) constraints the phi-function technique [16, 17] is employed. A mathematical model of KP for a given tuple can be formulated as the following nonlinear programming problem:

$$
\begin{gathered}
\min \lambda \text { s.t. } Y=\left(\lambda, u_{1}, u_{2}, \ldots u_{N}\right) \in \widehat{W} \subset \mathbf{R}^{d n+1}, \\
\widehat{W}=\left\{Y: \Phi_{i j}\left(u_{i}, u_{j}\right) \geq 0, i, j \in I_{N}, j>i,\right. \\
\left.\Phi_{i}(Y) \geq 0, i \in I_{N}, \lambda \geq 1\right\},
\end{gathered}
$$

where $u_{1}, u_{2}, \ldots u_{N}$ are motion vectors for spheres $S_{i}\left(u_{i}\right), i \in I_{N}$, function $\Phi_{i j}(Y), i, j \in I_{N}, j>i$, is a phi-function to ensure the non-overlapping constraint, function $\Phi_{i}(v), \quad i \in I_{N}$, is a phi-function for the containment constraints. Variable $\lambda$ occurs in all inequalities $\Phi_{i}(Y) \geq 0, i \in I_{N}$, describing interaction of spheres and container $\mathrm{C}\left(\lambda^{0}\right)$ and bounded from below by inequality $\lambda \geq 1$. To this end, $C \subset C(\lambda)$. 
Thus, problem (5)-(6) can be considered as ODP with open parameter $\lambda$. To solve the problem the jump algorithm can be efficiently applied.

A global minimum point $v^{*}=\left(\lambda^{*}, u_{1}^{*}, u_{2}^{*}, \ldots u_{N}^{*}\right)$ for problem (5)-(6) provides packing spheres $S_{i}\left(u_{i}^{*}\right), i \in N$, into container $C\left(\lambda^{*}\right) \equiv C, \lambda^{*}=1$, and corresponds to a solution of problem (1)-(2) for the given tuple. If at the point $v^{*}$ value $\lambda^{*}>1$, then $C \subset C(\lambda)$, i.e. we do not have original container and hense there is no a feasible packing corresponding to a solution of problem (1) - (2). The multistart strategy should be exploited to obtain the required size of the container.

A starting point to solve problem (5) - (6) can be calculated by solving the problem for container $C\left(\lambda^{0}\right)$ where $\lambda^{0}>1$ should provide a packing of the spheres according to the tuple $t$. In Fig.1 a starting point for the packing circles into the rectangle $C\left(\lambda^{0}\right), \lambda^{0}=1.1$ is shown. Solving problem by means of the jump algorithm leads to the packing illustrated in Fig. 2.

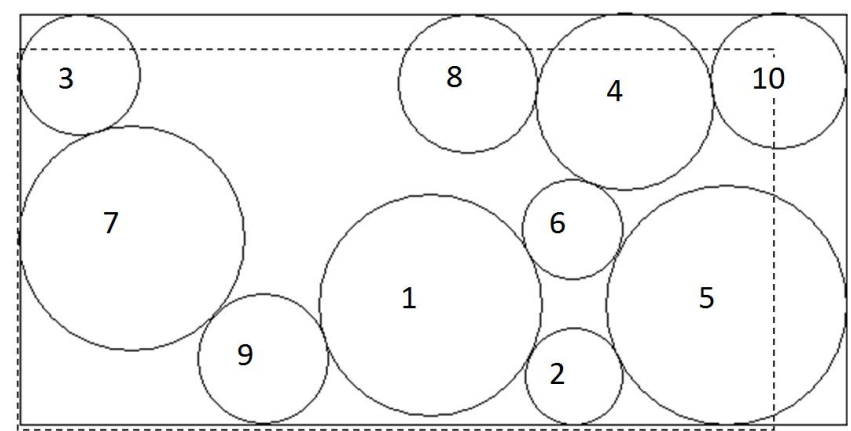

Fig. 1. Illustration of a packing of circles into the rectangle $C(1,1)$

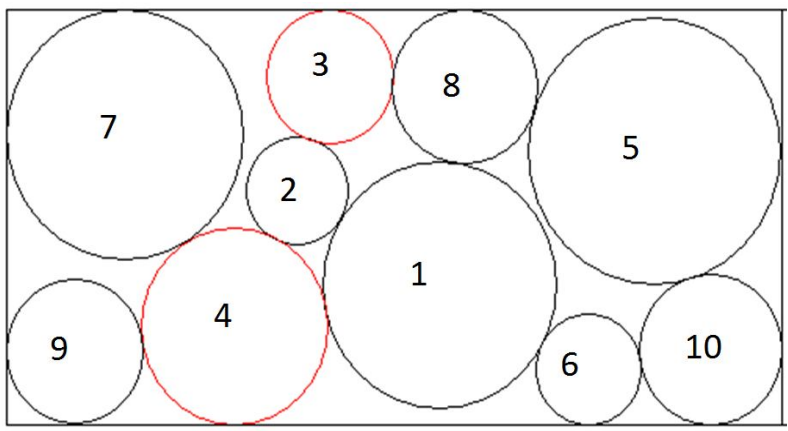

Fig. 2. The final packing of circles into the rectangle $C(1)$
Although, solving problem (5)-(6) does not save from an exhaustive search of tuples from the set $T$ such approach improve significantly quality of solution obtained due to high performance of the jump algorithm. The jump algorithm is suitable for packing unequal spheres. So, in order to pack equal spheres, another solution method of problem (5)-(6) is required. Any optimization procedure which gives a global solution of problem (5)-(6) can be applied.

\section{Conclusions}

The approach suggested in the paper allows to reduce KP to ODP and apply the known jump algorithm to solve KP for a given tuple. Such a transition was made possible by introducing a variable container size using the homothety coefficient. The approach is suitable for packing unequal and equal spheres into containers of arbitrary spatial shapes for which phifunctions can be constructed. The more complicated the spatial shape of the container, the harder to solve the problem.

Mathematical models constructed contribute to the field of cutting and packing to describe a common methodology to solve SPP. Further study of the properties of SPP and the development of effective solution methods is a priority for advance research.

\section{REFERENCES}

1. Hifi, M. and M'Hallah, R. (2009), "A literature review on circle and sphere packing problems: models and methodologies", Advances in Operations Research, Vol. 2009, available at: http://downloads.hindawi.com/journals/aor/2009/150624.pdf DOI: https://doi.org/10.1155/2009/150624

2. Leary, M., Merli, L., Torti, F., Mazur, M. and Brandt, M. (2014), "Optimal topology for additive manufacture: A method for enabling additive manufacture of support-free optimal structures", Materials and Design, Vol. 63, pp. 678-690.

3. Blyuss, O., Koriashkina, L., Kiseleva, E. and Molchanov, R. (2015), "Optimal Placement of Irradiation Sources in the Planning of Radiotherapy: Mathematical Models and Methods of Solving", Computational and Mathematical Methods in Medicine, Vol. 2015, p. 8, DOI: https://doi.org/10.1155/2015/142987

4. Agapie, S.C. and Whitlock, P.A. (2010), "Random packing of hyperspheres and Marsaglia's parking lot test", Monte Carlo Methods and Applications, Vol. 16(3-4), pp.197-209.

5. Conway, J. H. and Sloane, N.J.A. (2010), Sphere Packings, Lattices, and Groups, New York, Springer-Verlag, 703 p.

6. Torquato, S. (2006), "Exactly solvable disordered sphere-packing model in arbitrary-dimensional Euclidean spaces", Physical Review, vol. E 73, 031106.

7. Waescher, G. and Haussner, H. (2007), "An improved typology of cutting and packing problems", European Journal of Operational Research, Vol. 183, pp. 1109-1130.

8. Hifi, M. and Yousef, L. (2015), "A dichotomous search-based heuristic for the three-dimensional packing problem", Cogent Engineering, Vol. 1, pp. 1-15.

9. Hifi, M. and Yousef, L. (2019), "A local search-based method for sphere packing problems", European Journal of Operational Research, Vol. 274, Issue 2, pp. 482-500.

10. Birgin, E.G. and Sobral, F.N.C. (2008), "Minimizing the object dimensions in circle and sphere packing problems" Computers \& Operations Research, Vol. 35, pp. 2357-2375. 
11. Stoyan, Yu. and Yaskov, G. (2012), "Packing congruent hyperspheres into a hypersphere", Journal of Global Optimization, Vol. 52(4), pp. 855-868.

12. Yakovlev, S.V., Yaskov, G.N. and Korobchinskiy, K.P. (2017), "O metodah peremennogo radiusa v zadache upakovki sharov v konteynery [About variable radius methods in problems of packing spheres into containers]", Pytannya prikladnoyi matematyky i matematuchnogo modelyuvannya, DNU, Dnipro, Issue 17, pp. 265-272.

13. Stoyan, Yu.G., Scheithauer, G. and Yaskov, G.N. (2016), "Packing unequal spheres into various containers", Cybernetics and Systems Analysis, Vol. 52(3), pp. 419-426.

14. Yaskov, G.N. (2014), "Packing non-equal hyperspheres into a hypersphere of minimal radius", Problemy Mashinostroeniya, Vol. 17, No 2, pp. 48-53.

15. Stoyan, Yu. and Yaskov G. (2014), "Packing unequal circles into a strip of minimal length with a jump algorithm", Optimization Letters, Vol. 8(3), pp. 949-970.

16. Chernov, N., Stoyan, Yu., Romanova, T. (2010), "Mathematical model and efficient algorithms for object packing problem", Computational Geometry, Vol. 43(5), pp. 535-553.

17. Stoyan, Y., Pankratov, A. and Romanova, T. (2016), "Quasi-phi-functions and optimal packing of ellipses", Journal of Global Optimization, Vol. 65(2), pp. 283-307.

Received (Надійшла) 13.12.2018

Accepted for publication (Прийнята до друку) 20.02.2019

\title{
Методологічні основи розв'язання задачі упаковки куль: перетворення задачі про рюкзак у задачу зі змінним розміром
}

\author{
Г. М. Яськов, С. Б. Шеховцов
}

Предметом статті є задача оптимальної упаковки куль різної розмірності в контейнер довільної геометричної форми. Мета полягає в тому, щоб побудувати математичну модель, в якій зв'язуються різні формулювання задачі. Задача упаковки куль (SPP) є задачею комбінаторної оптимізації, відомою як задача розкрою й упаковки. SPP полягає в розміщенні заданого набору куль із заданими радіусами в контейнері правильної або неправильної геометричної форми. Задача, яку необхідно вирішити, полягає в тому, щоб: дослідити математичні моделі двох постановок відповідно до класифікації задач розкрою й упаковки: задачі про рюкзак (KP) та задачі зі змінним розміром (ODP); побудувати математичну модель, яка дозволяє розв'язати задачу KP як задачу ODP. Використовувані методи: метод рһі-функцій, збільшення розмірності задачі, гомотетичні перетворення. Задача КР формулюється як змішана задача дискретнонеперервного програмування. Пропонується новий підхід, в якому розв'язання задачі КР зводиться до розв'язання задачі ODP для упаковки нерівних і рівних куль у контейнері зі змінним коефіцієнтом гомотетії й який дозволяє використовувати јuтр-алгоритм для задачі КР. 3 цією метою задача КР для даного набору куль представляється у вигляді задачі нелінійного програмування, в якій коефіцієнт гомотетії розглядається в якості незалежної змінної, обмеженою знизу. Коефіцієнт гомотетії, який дорівнює одиниці, відповідає початковому розміру контейнера. Зображена графічна ілюстрація процесу оптимізації. Висновки. Запропонований підхід є методологічною основою для розв'язання задачі SPP. Універсальність підходу полягає в тому, що розв'язання задачі не залежить від іiї постановки (KP або ODP). Підхід застосовний для упаковки нерівних і рівних куль у контейнерах довільних просторових форм, для яких можуть бути побудовані phi-функції.

Ключові слов а : куля; гіперкуля; упаковка куль; задача про рюкзак; задача зі змінним розміром; нелінійна оптимізація.

\section{Методологические основы решения задачи упаковки шаров: преобразование задачи о рюкзаке в задачу с переменным размером}

\section{Г. Н. Яськов, С. Б. Шеховцов}

Предметом статьи является задача оптимальной упаковки шаров разной размерности в контейнер произвольной геометрической формы. Цель состоит в том, чтобы построить математическую модель, в которой связываются различные формулировки задачи. Задача упаковки шаров (SPP) является задачей комбинаторной оптимизации, известной как задача раскроя и упаковки. SPP заключается в размещении заданного набора шаров с заданными радиусами в контейнере правильной или неправильной геометрической формы. Задача, которую необходимо решить, состоит в том, чтобы: исследовать математические модели двух постановок в соответствии с классификацией задач раскроя и упаковки: задачи о рюкзаке (KP) и задачи с переменным размером (ODP); построить математическую модель, позволяющую решить задачу KP как задачу ODP. Используемые методы: метод рhі-функций, увеличение размерности задачи, гомотетические преобразования. Задача КР формулируется как смешанная задача дискретно-непрерывного программирования. Предлагается новый подход, в котором решение задачи КР сводится к решению задачи ODP для упаковки неравных и равных шаров в контейнере с переменным коэффициентом гомотетии и который позволяет использовать јuтр-алгоритм для задачи КР. С этой целью задача КР для данного набора шаров представляется в виде задачи нелинейного программирования, в которой коэффициента гомотетии выступает в качестве независимой переменной, ограниченной снизу. Коэффициент гомотетии, равный единице, соответствует исходному размеру контейнера. Представлена графическая иллюстрация процесса оптимизации. Выводы. Предложенный подход является методологической основой для решения задачи SPP. Универсальность подхода заключается в том, что решение задачи SPP не зависит от ее постановки (KP или ODP). Подход применим для упаковки неравных и равных шаров в контейнерах произвольных пространственных форм, для которых могут быть построены рhі-функции.

Ключевые слова: шар; гипершар; упаковка шаров; задача о рюкзаке; задача с переменным размером; нелинейная оптимизация. 